\title{
Perbandingan Hasil Belajar Fisika Menggunakan Metode Eksperimen Dan Metode Demonstrasi Siswa Kelas VIII SMP TMI Roudlatul Quran Metro
}

\author{
Erni Mariana ${ }^{1}$ \\ 1 Universitas Nahdlatul Ulama Lampung \\ Coressponding Author. E-mail: \\ ${ }^{1}$ marianaerni558@gmail.com
}

Received: 1 Mei 2019

Accepted: 28 Juli 2019

Online Published: 30 Juli 2019

\begin{abstract}
Abstrak
Hasil belajar siswa kelas VIII SMP TMI Roudlatul Qur'an Metro berdasarkan hasil Pra-survey masih banyak yang belum memenuhi KKM. Dalam proses pembelajaran siswa menganggap pelajaran fisika sebagai pelajaran yang sulit dan rumit, siswa kurang menanggapi atau mengajukan pertanyaan, dan kurang rasa tanggung jawab siswa dalam menyelesaikan tugas-tugas. Penelitian ini bertujuan: (1). untuk mengetahui perbedaan hasil pembelajaran fisika dengan menggunakan metode eksperimen dan metode demonstrasi, (2). untuk mengetahui metode mana yang lebih tinggi rata-rata hasil belajar fisika menggunakan metode eksperimen dan metode demonstrasi. Sampel adalah kelas VIII A diajar dengan metode Eksperimen, dan kelas VIII B menggunakan metode Demonstrasi. Objek penelitian 60 orang, terdiri dari 30 orang kelas VIII A dan 30 orang kelas VIII B, dipilih secara random. Penelitian ini menggunakan perhitungan uji normalitas, uji homogenitas, uji kesamaan dua rata-rata, dan uji perbedaan dua rata-rata. Hasil penelitian menunjukkan, dari perhitungan uji kesamaan dua rata-rata diperoleh $t_{\text {hit }}>t_{\text {daf }}$, berarti (1) Ada perbedaan rata-rata hasil belajar fisika siswa yang mendapatkan pelajaran dengan menggunakan metode eksperimen dan metode demonstrasi. Dari perhitungan uji perbedaan dua rata-rata diperoleh $t_{h i t}>t_{d a f}$, berarti (2) rata-rata hasil belajar fisika siswa yang mendapatkan pelajaran dengan pemberian metode eksperimen lebih tinggi dari ratarata hasil belajar fisika siswa yang mendapatkan pelajaran dengan pemberian metode demonstrasi.
\end{abstract}

Kata Kunci: Metode Eksperimen; Metode Demonstrasi; Hasil Belajar.

\begin{abstract}
The learning result of class VIII SMP TMI ROUDLATUL QURAN METRO based on on pra survey result that still many do not complete of minimum creterium. On learning process student to a physics as a difficult and complicated lesson, student less of respond ar ask a question, and less of student responsibility to do homework, that teacher given. This research was proposed: (1).To know the different result of learning physics by using experimental method and demonstration method, (2). To determine the difference which method higher an average of the learning physics using the experimental method and demonstration method. The samples of this research were VIII A which was taught by the experiment method and VIII B by the demonstration method. The total of students were 60, consist of 30 people in VIII $A$ and 30 people in VIII B, who were randomly selected. The research used the calculation of the normality test, homogenity test, two average similarity test, and two average difeference test as the data analysis technique. Result in this research is from the accounts test in common two averages obtained $t_{\text {hit }}>t_{\text {daf }}$,so (1) there is the difference an average of the learning of physics students who get learning using experiment method from yhe accounts test common two averages obtained $t_{\text {hit }}>t_{\text {daf }}$,so (2) average of the learning outcome of physics students taught by experimen method is higher than an average of the learning outcome of physics students with using demonstration method.
\end{abstract}

Keywords: Experiment Method; Demonstration Method; Learning Outcome

How to cite this article :

Mariana, E. (2019). Perbandingan Hasil Belajar Fisika Menggunakan Metode Eksperimen Dan Metode Demonstrasi Siswa Kelas VIII SMP TMI Roudlatul Quran Metro. IJIS Edu : Indonesian Journal of Integrated Science Education, 1(2). doi:http://dx.doi.org/10.29300/ijisedu.v1i2.1871 


\section{PENDAHULUAN}

Pendidikan adalah usaha sadar untuk menumbuh kembangkan potensi Sumber Daya Manusia (SDM) melalui kegiatan pembelajaran. Pendidikan memegang peranan yang penting untuk menjamin kelangsungan hidup berbangsa dan bernegara, karena pendidikan merupakan wahana untuk meningkatkan mutu pendidikan nasional. Salah satunya yaitu dengan melakukan perbaikanperbaikan pada sistem pendidikan. Usaha perbaikan dan perubahan ini mencakup berbagai aspek seperti perbaikan mutu guru, perbaikan kurikulum dan perbaikan dalam proses pembelajaran.

Belajar dengan cara menggunakan suatu percobaan atau praktikum sangatlah penting karena dapat merangsang pemikiran siswa untuk lebih aktif lagi dalam proses pembelajaran. Sebagai halnya yang sudah dilakukan oleh guru SMP TMI Roudlatul Qur'an Metro khususnya bidang fisika, akan tetapi guru hanya menerapkan metode demonstrasi untuk melakukan proses pembelajarannya sehingga siswa sebagian besar tidak menangkap apa yang didemonstrasikan oleh guru di depan kelas karena kurang terkondisi, seperti ada siswa yang tidak memperhatikan pada saat guru mendemonstrasikan, banyak siswa yang mengobrol dalam proses pembelajaran berlangsung, banyak siswa yang segan bertanya kepada guru apabila kurangn paham, dan masih banyak siswa yang belum mengenal dan melakukan percobaan alat yang didemonstrasikan guru.

Purwanto (2000) menyatakan bahwa Belajar adalah aktivitas mental/psikis yang berlangsung dalam interaksi aktif dengan lingkungan yang menghasilkan perubahan-perubahan dalam pengetahuan, keterampilan dan sikap. (Juhri, 2006) menyatakan bahwa Perubahan itu diperoleh melalui usaha (bukan karena kematangan), menetap dalam waktu yang relatif lama dan merupakan hasil pengalaman. Belajar adalah suatu proses yang aktif, artinya orang yang belajar itu ikut serta dalam proses itu dengan aktif. Orang yang belajar itu mempelajari apa yang sedang dilakukannya, apa yang dirasakan dan apa yang dipikirkannya. Di dalam interaksi inilah terjadi serangkaian pengalaman belajar. Jadi, belajar adalah proses perubahan tingkah laku individu ke arah yang lebih baik dan bersifat relatif tetap akibat adanya interkasi latihan yang dialaminya.

Mulyadi (2008) menyatakan bahwa metode kerja kelompok adalah penyajian dengan cara pemberian tugas-tugas untuk mempelajari sesuatu kepada kelompok-kelompok belajar yang sudah ditentukan dalam rangka mencapai tujuan. Dalam kerja kelompok yang terpening adalah interaksi antara anggota kelompok dan dari interaksi ini diharapkan akan terjadi perbaikan pada diri murud yang mengalami kesulitan dalam belajar. Peranan guru dalam pembelajaran melalui kerja kelompok adalah: 1) Organisator dalam proses kelompok. 2) Sumber informasi bagi siswa dalam penyelesaian tugas kelompok. 3) Pendorong bagi siswa untuk belajar. 4) Penyedia informasi dan pemberian kesimpulan kepada semua siswa untuk partisipasi dalam proses kelompok. 5) Orang yang mendiagnosa kesulitan siswa serta memberikan bantuan yang sesuai kebutuhan. 6) Ikut aktif sebagai peserta kegiatan.

Data hasil pra survei tentang hasil belajar siswa kelas VIII SMP TMI Roudlatul Quran Metro dapat dilihat sebagai berikut:

Table 1. Data Nilai Hasil Belajar Siswa Kelas VIII Semester Genap SMP TMI Roudlatul Quran Metro

\begin{tabular}{ccccc}
\hline No & KKM & Kategori & $\begin{array}{c}\text { Jumlah } \\
\text { Murid }\end{array}$ & Presentase \\
\hline 1. & $<70$ & $\begin{array}{l}\text { Tidak } \\
\text { Tuntas }\end{array}$ & 24 & $68 \%$ \\
\hline 2. & $\geq 70$ & Tuntas & 12 & $32 \%$ \\
\hline & JUMLAH & 36 & $100 \%$ \\
\hline
\end{tabular}

Berdasarkan Tabel 1, dapat dilihat bahwa rata-rata hasil belajar fisika siswa SMP Kartikatama Metro belum mencapai hasil yang diinginkan, karena nilai kebanyakan siswa belum mencapai KKM yang ditetapkan yaitu 70 . Hal ini dapat dilihat dari jumlah siswa yang belum tuntas sebanyak $68 \%$ dan siswa yang telah tuntas sebanyak $32 \%$. Jelas terlihat dari hasil nilai yang didapatkan bahwa kelas VIII SMP TMI Roudlatul Quran Metro mengalami kesulitan dalam hal memahami materi fisika. Maka dari itu perlu adanya suatu perbaikan dalam proses pembelajaran agar hasil belajar siswa sesuai dengan apa yang diharapkan.

1. Berdasarkan pra survei yang peneliti lakukan rendahnya hasil belajar fisika kelas VIII di SMP TMI Roudlatul Quran Metro yang dapat di identifikasikan disebabkan oleh; Kurangnya pengorganisasian kelas yang efektif, seperti pengelompokan siswa secara klasikal dalam belajar.

2. Masih terdapat siswa yang tidak memperhatikan saat proses pembelajaran seperti mengobrol dengan temannya ketika berada di dalam kelompoknya. 
3. Siswa yang pandai lebih mendominasi di dalam kelompoknya dalam pembelajaran maupun mengerjakan soal.

4. Di dalam suatu kelompok masih terdapat siswa yang tidak bisa mengerjakan latihan maupun soal.

5. Kurang efektifnya pembentukan kelompok, seperti pengelompokan siswa yang tidak mempertimbangkan kemampuan siswa sehingga terdapat kelompok yang tidak efektif mengerjakan tugas.

Berdasarkan wawancara dengan guru IPA di SMP SMP TMI Roudlatul Quran Metro, diperoleh suatu keterangan bahwa pada saat belajar fisika, guru telah menggunakan metode demonstrasi untuk merangsang pemikiran siswa terhadap materi yang diajarkan ternyata masih banyak sekali hasil belajar siswa yang menurun di bawah standar KKM. Oleh sebab itu, ingin membandingkan metode demonstrasi dengan metode eksperimen dalam pembelajaran fisika, guna ingin mengetahui bahwa metode mana yang cocok untuk melakukan pembelajaran tersebut. Eksperimen adalah kegiatan yang direncanakan dan dilaksanakan oleh peneliti untuk mengumpulkan bukti-bukti yang ada hubungannya dengan hipotesis (Agustriana, 2013; Besral, Rizal, \& Tawahusna, 2018; Desi Putrianasari \& Wasitohadi, 2015). Peneliti dengan sengaja dan secara sistematis memasukan perubahanperubahan ke dalam gejala-gejala alamiah dan kemudian mengamati akibat dari perubahan yang dimasukan itu.

Berdasarkan masalah di atas, maka hasil belajar dengan menggunakan metode eksperimen dan metode demontrasi dalam proses pembelajaran bisa sangat membantu bagi siswa maupun guru. Dengan pertimbangan inilah yang mendorong untuk meneliti masalah ini, mengingat pentingnya suatu pola pengajaran yang tepat. Sehubungan dengan hal tersebut di atas, maka akan melaksanakan penelitian dengan judul "Perbandingan Hasil Belajar Fisika Menggunakan Metode Eksperimen dan Metode Demonstrasi Siswa Kelas VIII SMP TMI Roudlatul Quran Metro".

Berdasarkan latar belakang di atas maka rumusan masalah dalam penelitian ini adalah, 1. Apakah ada perbedaan rata-rata hasil belajar fisika menggunakan metode eksperimen dan metode demonstrasi siswa kelas VIII SMP TMI Roudlatul Quran Metro?, 2. Untuk mengetahui metode mana yang lebih tinggi rata-rata hasil belajar fisika menggunakan metode eksperimen dan metode demonstrasi?.
Adapun tujuan penelitian ini adalah, untuk mengetahui adanya perbedaan rata-rata hasil belajar fisika menggunakan metode eksperimen dan metode demonstrasi siswa kelas VIII SMP TMI Roudlatul Quran Metro dan untuk mengetahui metode mana yang lebih tinggi rata-rata hasil belajar fisika menggunakan metode eksperimen dan metode demonstrasi.

\section{METODE}

Jenis penelitian ini adalah komparatif yaitu membandingkan rata-rata hasil belajar fisika siswa antara pembelajaran menggunakan metode eksperimen dan metode demonstrasi melalui pembelajaran kelompok. Dalam proses pelaksanaan, kedua kelas yang telah dipilih pembelajarannya menggunakan metode eksperimen dan metode demostrasi, evaluasi pembelajaran dapat dilakukan dengan cara individu. Rizkiana, Dasna, \& Marfu'ah, (2016); Wilantara \& Priyanto, 2014) menyatakan bahwa Metode demonstrasi ialah metode mengajar dengan menggunakan peragaan untuk memperjelas suatu pengertian atau untuk memperlihatkan bagaimana berjalannya suatu proses pembentukan tertentu pada siswa. Untuk memperjelas pengertian tersebut dalam prakteknya dapat di lakukan oleh guru atau anak didik itu sendiri .

Arikunto (2014) menyatakan bahwa pada pemilihan sampel ini dipilih secara Cluster Rondom Sampling. Sampel dari penelitian ini adalah kelas VIII A diajar dengan metode Eksperimen dan kelas VIII B dengan menggunakan metode Demonstrasi. Jumlah siswa keseluruhan yang menjadi objek penelitian adalah 60 orang, yang terdiri dari 30 orang kelas VIII A dan 30 orang kelas VIII B.

Sebelum penelitian dilaksanakan maka untuk memperoleh hasil pengukuran data yang valid (sahih) dan reliabel, dilakukan validitas instrument melalui penilaian ahli yang terdiri dari 3 validator dan untuk reabilitas tes yang akan digunakan. Teknik analisis data yang digunakan dalam penelitian ini meliputi uji normalitas sampel, uji homogenitas dan uji perbedaan dua rata-rata.

\section{HASIL DAN PEMBAHASAN}

Berdasarkan hasil penelitian yang telah dilakukan, perolehan data hasil belajar siswa yang diperoleh setelah melakukan pretest (tes awal) dan posttest (tes akhir), dan perhitungan data nilai ratarata hasil belajar siswa serta jumlah siswa dapat dilihat pada lampiran. Adapun ringkasan deskripsi data disajikan dalam tabel berikut:
a. Siswa dengan pemberian Metode Demonstrasi kelas VIIIA dan Metode 
Eksperimen kelas VIIIB pada meteri Getaran dan Gelombang.

1. Uji Normalitas Data

Table 2. Uji Normalitas Hasil Belajar Siswa

\begin{tabular}{cccccc}
\hline \multicolumn{5}{c}{ Uji Kecocokan chi kuadrat } & \\
& $X^{2}{ }_{\text {hit }}$ & Dk & $\begin{array}{c}X^{2} \text { daffar } \\
(\alpha=0,05)\end{array}$ & $\begin{array}{c}X^{2} \text { daftar } \\
(\alpha=0,0 \\
1)\end{array}$ & $\begin{array}{c}\text { Kesimpu } \\
\text { lan }\end{array}$ \\
\hline Demonstrasi & 4,19 & 3 & 7,81 & 11,3 & $\begin{array}{c}\text { Berdistri } \\
\text { busi } \\
\text { Normal }\end{array}$ \\
\hline Eksperimen & 4,49 & 3 & 7,81 & 11,3 & $\begin{array}{c}\text { Berdistri } \\
\text { busi } \\
\text { Normal }\end{array}$ \\
\hline
\end{tabular}

Berdasarkan Tabel 2, dapat dijelaskan beberapa hal yaitu diketahui bahwa $X_{\text {hit }}^{2}<X^{2}$ daftar baik pada kelas dengan pemberian metode demonstrasi maupun metode eksperimen Dapat dilhat pada kelas dengan pemberian metode demonstrasi $X^{2}$ bit $=4,19<$ $X_{\text {daftar }(\alpha=0,05) \text { dan }(\alpha=0,01)}=7,81$ dan 11,3 dan pada kelas dengan pemberian metode eksperimen $X^{2}{ }_{\text {bit }}=4,49<$

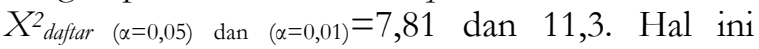
menyatakan bahwa hasil belajar siswa sebagai hipotesis berdistribusi normal atau terima $\mathrm{H}_{0}$ dengan kriteria uji terima $\mathrm{H}_{0}$ jika $x_{h i t}^{2} \leq x_{(1-\alpha)(k-3)}^{2}$

2. Uji Kesamaan Dua Varians (Uji Homogenitas)

Table 3. Uji Kesamaan Dua Varians (Uji Homogenitas) Hasil Belajar Fisika Siswa

\begin{tabular}{llll}
\hline$F_{\text {bit }}$ & $\begin{array}{l}F_{\text {daftar }} \\
(\alpha=0,05)\end{array}$ & $F_{\text {daffar }}(\alpha=0,01)$ & Kesimpulan \\
\hline 1,06 & 1,98 & 2,66 & Homogen \\
\hline
\end{tabular}

Berdasarkan Tabel 3, dapat dijelaskan beberapa hal yaitu diketahui $F_{\text {hitung }}=1,06<\mathrm{F}_{\text {daftar }}$ $(\alpha=0,05)$ dan $(\alpha=0,01)=1,98$ dan 2,66. Hal ini berarti hipotesis yang menyatakan varians hasil belajar pada kelas dengan pemberian metode demonstrasi dan kelas dengan pemberian metode eksperimen adalah homogen atau terima $\mathrm{H}_{0}$. Dengan kriteria uji terima $\mathrm{H}_{0}$ adalah $\boldsymbol{F}_{h i t} \leq \boldsymbol{F}_{\frac{1}{2} \alpha\left(v_{1}, v_{2}\right)}$.

3. Uji Hipotesis

a. Tes Kesamaan Dua Rata-Rata
Uji Kesamaan Dua Rata-Rata Hasil Belajar Fisika Siswa

Table 4. Uji Kesamaan Dua Rata-Rata Hasil Belajar Fisika Siswa

\begin{tabular}{c|c|c|c}
\hline$t_{\text {hit }}$ & $\begin{array}{c}t_{\text {daffar }} \\
(\alpha=5 \%)\end{array}$ & $\begin{array}{c}t_{\text {daftar }} \\
(\alpha=1 \%)\end{array}$ & Kesimpulan \\
\hline 2,95 & 2,02 & 2,70 & $\mathrm{H}_{1}$ diterima \\
\hline
\end{tabular}

Berdasarkan Tabel 4, dapat dijelaskan beberapa hal yaitu diketahui $t_{\text {hitung }}=2,95>\mathrm{t}_{\text {daftar }}$ $(\alpha=5 \%)$ dan ${ }_{(\alpha=1 \%)}=2,02$ dan 2,70 . Hal ini berarti hipotesis yang menyatakan kesamaan dua rata-rata hasil belajar pada kelas dengan pemberian metode demonstrasi dan kelas dengan pemberian metode eksperimen adalah ada perbedaan rata-rata hasil belajar fisika siswa atau $\mathrm{H}_{1}$ dengan kriteria $t_{\text {hit }}>t_{d a f}$
b. Tes Perbedaan Dua Rata-Rata c.

Table 5. Uji Perbedaan Dua Rata-Rata Hasil Belajar Fisika Siswa

\begin{tabular}{cccc}
\hline$t_{\text {bit }}$ & $\begin{array}{c}t_{\text {daftar }} \\
(\alpha=5 \%)\end{array}$ & $\begin{array}{c}t_{\text {daffar }} \\
(\alpha=1 \%)\end{array}$ & Kesimpulan \\
\hline 2,8 & 1,68 & 2,46 & $\mathrm{H}_{1}$ diterima \\
\hline
\end{tabular}

Berdasarkan Tabel 5 , dapat dijelaskan beberapa hal yaitu diketahui $t_{\text {hitung }}=2,8>\mathrm{t}_{\text {daftar }}$ ${ }_{(\alpha=5 \%)} \quad$ dan ${ }_{(\alpha=1 \%)}=1,68$ dan 2,46. Hal ini mengindikasikan penolakan pada $\mathrm{H}_{0}$, sehingga dapat disimpulkan bahwa rata-rata hasil belajar fisika siswa melalui pemberian metode eksperimen lebih tinggi daripada rata-rata hasil belajar fisika siswa melalui pemberian metode demonstrasi.

Secara teoritis, perbedaan tersebut didasarkan pada perbedaan aktivitas yang dilakukan oleh siswa selama proses pembelajaran berlangsung. Hal ini terlihat dari persentase aktivitas yang diamati observer. Dari fakta lapangan diketahui bahwa dalam proses pembelajaran berlangsung, pada kelas yang pembelajarannya dengan pemberian metode eksperimen terlihat bahwa sebagian besar siswa aktif ketika saat siswa presentasi ke depan kelas dan banyak dari salah satu kelompok siswa yang aktif bertanya serta memberikan tanggapan kepada kelompok yang presentasi dibandingkan pada proses pembelajaran menggunakan metode demonstrasi. 
Morrisan (2012) menyatakan bahwa Penelitian eksperimen sangat sesuai untuk pengujian hipotesis dan dimaksudkan untuk mengetahui sebab akibat.

Adapun kekurangan dan kelemahan dari pembelajaran bahwa terdapat faktor lain disamping hal yang telah dijelaskan di atas tentang proses pembelajaran menggunakan metode demonstrasi yaitu masih banyak siswa yang ribut sendiri-sendiri dalam kelompoknya tidak memperhatikan guru sedang mendemonstrasikan di depan kelas, pembelajaran pun juga kurang efektif karena hanya beberapa perwakilan siswa yang terlibat langsung dalam demonstrasi di depan kelas tidak keseluruhan siswa sehingga membuat siswa yang lainnya tidak ikut serta dalam mendemonstrasikan, hal umum dialami oleh para guru seperti Juita (2019); Julaila (2019); K. Wiyono, Liliasari Liliasari, A. Setiawan, (2012); Kusumah \& Munandar, (2017). Oleh sebab itu peneliti simpulkan bahwa apabila guru menggunakan metode demonstrasi saja maka siswa akan merasa jenuh dan mereka juga kurang leluasa dalam mengetahui cara praktikum, sehingga perlu adanya metode yang lain dan tepat untuk meningkatkan hasil belajar siswa pada materi getaran dan gelombang. Istilah kerja kelompok dipakai untuk merangkum pengertian di mana anak didik dalam satu kelompok dipandang sebagai satu kesatuan sendiri, untuk mencari tujuan pelajaran yang tentu dengan bergotong royong. Falentina (2017) menyatakan bahwa Metode kerja kelompok atau bekerja dalam situasi kelompok, mengandung pengertian bahwasiswa dalam satu kelas dipandang sebagai satu kesatuan (kelompok) tersendiri, ataupun dibagi atas kelompok-kelompok kecil atau sub-sub kelompok.

\section{SIMPULAN DAN SARAN Simpulan}

Berdasarkan hasil analisis data penelitian ini, diperoleh kesimpulan. Ada perbedaan yang nyata rata-rata hasil belajar fisika siswa yang diajar menggunakan metode eksperimen dengan rata-rata hasil belajar siswa yang diajar dengan metode demonstrasi pada pokok bahasan hukum newton siswa kelas VIII SMP TMI Roudlatul Qur'an Metro. Rata-rata hasil belajar fisika siswa yang diajar menggunakan metode eksperimen lebih tinggi dari rata-rata hasil belajar siswa yang diajar dengan menggunakan metode demonstrasi pada pokok bahasan hukum newton siswa kelas VIII SMP TMI Roudlatul Qur'an Metro.

\section{Saran}

Berdasarkan kesimpulan yang diperoleh selama melaksanakan penelitian dan hasil pengamatan dalam pelaksanaan penelitian, maka penulis mencoba mengemukakan saran-saran guna meningkatkan hasil belajar siswa dalam bidang studi matematika sebagai berikut:

Dalam rangka meningkatkan hasil belajar siswa bidang studi fisika adalah dalam menyampaikan pokok bahasan materi getaran dan gelombang lebih efektif dengan menggunakan metode eksperimen karena siswa dapat saling bekerjasama dan aktif serta sama-sama menuangkan hasil pemikiran guna mencapai suatu hasil belajar baik secara individu maupun dalam kelompok siswa hasil belajarnya menjadi lebih baik dan meningkat.

Pada proses belajar mengajar guru sebagai pelaksana proses pendidikan hendaknya dalam melakasanakan tugas pengajaran itu dengan baik dan yang dapat mengajak siswa aktif dalam proses pembelajaran serta dapat memotivasi siswa untuk belajar lebih giat. Hal ini dapat diatasi dengan penggunaan metode yang tepat disamping penyampaian materi yang menarik

\section{REFERENCES}

Agustriana, N. (2013). Pengaruh Metode Edutainment Dan Konsep Diri Terhadap Keterampilan Sosial Anak. Jurnal Pendidikan Usia Dini, 7(2), 267-286. Retrieved from http://journal.unj.ac.id/unj/index.php/jpu $\mathrm{d} /$ article/view/3881

Arikunto, S. (2014). Metode Penelitian Kuantitatif, Kualitatif, dan Kombinasi (Mixed Methods). Bandung: Alfabeta.

Besral, B., Rizal, S., \& Tawahusna, T. (2018). The Effect of Round Table Technique to Students' Writing Ability in Senior High School 12 Padang. At-Ta'lim : Media Informasi Pendidikan Islam, 17(2), 201-210. Retrieved from

http://ejournal.iainbengkulu.ac.id/index.ph $\mathrm{p} /$ attalim/article/view/1411

Desi Putrianasari, D., \& Wasitohadi, W. (2015). PENGARUH PENERAPAN PENDEKATAN CONTEXTUAL TEACHING AND LEARNING (CTL) TERHADAP HASIL BELAJAR MATEMATIKA DITINJAU DARI MOTIVASI BELAJAR SISWA KELAS 5 SD NEGERI CUKIL 01 KECAMATAN TENGARAN - KABUPATEN SEMARANG. Scholaria: Jurnal Pendidikan Dan Kebudayaan, 5(1), 57. 
https://doi.org/10.24246/j.scholaria.2015. v5.11.p57-77

Falentina, U. (2017). Memanfaatkan Metode Kerja Kelompok dalam Model Direct Instruction Untuk Mengoptimalkan Peningkatan Prestasi Belajar Matematika Siswa Kelas 8 Semester I Tahun Pelajaran 2015/2016 DI SMPN 8 Bintan. JIPM Jurnal Ilmiah Pendidikan Matematika), 5(2), 131. https://doi.org/10.25273/jipm.v5i2.1176

Juhri, A. (2006). Landasan dan Wawasan Pendidikan Suatu Pendekatan Kopetensi Guru. Metro: UM Metro Press.

Juita, R. (2019). Meningkatkan Hasil Belajar IPA Melalui Metode Eksperimen Pada Siswa Kelas IV SDN 02 Kota Mukomuko. IJIS Edu: Indonesian Journal of Integrated Science Education, 1(1), 43-50. Retrieved from http://ejournal.iainbengkulu.ac.id/index.ph $\mathrm{p} / \mathrm{ijisedu}$

Julaila. (2019). Upaya Meningkatkan Hasil Belajar IPA Siswa Kelas IV SDN 01 Mukomuko Menggunakan Media Torso. IJIS Edu: Indonesian Journal of Integrated Science Education, 1(1), 51-62. Retrieved from http://ejournal.iainbengkulu.ac.id/index.ph $\mathrm{p} /$ ijisedu

K. Wiyono, Liliasari Liliasari, A. Setiawan, C. T. P. (2012). Model Multimedia Interaktif Berbasis Gaya Belajar untuk Meningkatkan Penguasaan Konsep Pendahuluan Fisika Zat Padat. Jurnal Pendidikan Fisika Indonesia, 8, 74-82.

https://doi.org/10.15294/jpfi.v8i1.1997
Kusumah, R. G. T., \& Munandar, A. (2017). Analysis Of The Relationship Between Self Efficacy And Healthy Living Conciousness Toward Science Learning Outcome. EDUSAINS, 9(2), 132-138. https://doi.org/10.15408/ES.V9I2.2183

Morrisan, M. A. (2012). Metode Penelitian Survei. Jakarta: Kencana.

Mulyadi. (2008). Diagnosis Kesulitan Belajar dan Bimbingan Terhadap Kesulitan Khusus. Yogyakarta: Nuha Litera.

Purwanto, N. (2000). Psikologi pendidikan remaja. Bandung: Remaja Rosdakarya.

Rizkiana, F., Dasna, I. W., \& Marfu'ah, S. (2016). PENGARUH PRAKTIKUM DAN DEMONSTRASI DALAM PEMBELAJARAN INKUIRI TERBIMBING TERHADAP MOTIVASI BELAJAR SISWA PADA MATERI ASAM BASA DITINJAU DARI KEMAMPUAN AWAL. Jurnal Pendidikan: Teori, Penelitian, Dan Pengembangan, 1(3), 354 362.

https://doi.org/10.17977/JP.V1I3.6161

Wilantara, B., \& Priyanto, S. (2014). Pengaruh Metode Demonstrasi Terhadap Prestasi Belajar Mata Pelajaran Pemeliharaan/servisSistem Pengapian Konvensional Siswa Kelas XI Semester Genap SMK Tamansiswa Yogyakarta TahunAjaran 2013/2014. TAMAN VOKASI, 2(2). https://doi.org/10.30738/jtvok.v2i2.81 